\title{
A New System for the Spectrophotometric Determination of Trace Amounts of Nitrite in Environmental Samples
}

\author{
Tom Cherian and Badiadka Narayana* \\ Department of Post Graduate Studies and Research in Chemistry, Mangalore University, \\ Mangalagangothri -574 199, India
}

\begin{abstract}
Apresentamos um método espectrofotométrico seletivo e rápido para determinação de nitrito. $\mathrm{O}$ princípio do método é a reação do nitrito com $p$-nitroanilina, em meio ácido, formando o íon diazônio. O íon complexa com 2-etoxi maleato de dietila ou etilenoacetato, em meio básico, formando pigmentos tipo azo, com absorção máxima a 439 e $465 \mathrm{~nm}$, respectivamente. O método obedece a lei de Beer no intervalo de $0,5-15 \mu \mathrm{g} \mathrm{mL}^{-1}$ para o nitrito com 2-etoxi maleato de dietila, e $0,2-12 \mu \mathrm{g} \mathrm{mL}^{-1}$ para o nitrito com etileno acetato. A absortividade molar e a sensitividade de Sandell encontradas para os respectivos pigmentos azo foram $5,04 \times 10^{4} \mathrm{~L} \mathrm{~mol}^{-1} \mathrm{~cm}^{-1}, 0,98 \times 10^{-2} \mu \mathrm{g}$ $\mathrm{cm}^{-2} \mathrm{e} 1,21 \times 10^{4} \mathrm{~L} \mathrm{~mol}^{-1} \mathrm{~cm}^{-1}, 0,98 \times 10^{-2} \mu \mathrm{g} \mathrm{cm}^{-2}$. Foram avaliadas as condições ótimas de reação, bem como outros parâmetros analíticos. $\mathrm{O}$ método foi aplicado com sucesso na determinação de nitrito em várias amostras de água e solos.
\end{abstract}

A selective and rapid spectrophotometric method for the determination of nitrite is presented. It is based on the reaction of nitrite with $p$-nitroaniline in acid medium to form diazonium ion, which is coupled with ethoxyethylenemaleic ester or ethylcyanoacetate in basic medium to form azo dyes, showing absorption maxima at 439 and $465 \mathrm{~nm}$ respectively. The method obeys Beer's law in the concentration range of $0.5-16 \mu \mathrm{g} \mathrm{mL}^{-1}$ of nitrite with ethoxyethylenemaleic ester and $0.2-18 \mu \mathrm{g} \mathrm{mL}^{-1}$ of nitrite with ethylcyanoacetate. The molar absorptivity and Sandell's sensitivity of $p$-nitroaniline-ethoxyethylenemaleic ester and $p$-nitroaniline-ethylcyanoacetate azo dyes are $5.04 \times 10^{4} \mathrm{~L} \mathrm{~mol}^{-1} \mathrm{~cm}^{-1}, 0.98 \times 10^{-2} \mu \mathrm{g} \mathrm{cm}^{-2}$ and $1.21 \times 10^{4} \mathrm{~L} \mathrm{~mol}^{-1} \mathrm{~cm}^{-1}, 0.98 \times 10^{-2} \mu \mathrm{g} \mathrm{cm}^{-2}$ respectively. The optimum reaction conditions and other analytical parameters were evaluated. The method was successfully applied to the determination of nitrite in various water samples and soil samples.

Keywords: spectrophotometry, diazotization, nitrite, $p$-nitroaniline, ethoxyethylenemaleic ester, ethylcyanoacetate

\section{Introduction}

Nitrogen forms two environmental important oxyacids: nitrous acid and nitric acid. Corresponding nitrite and nitrate anions are common in the environment. In aquatic systems, nitrite is formed by biological oxidation of ammonium, and converted subsequently to nitrate. Nitrite is a characteristic pollutant. ${ }^{1}$ High concentrations of nitrite are present in industrial water, sewage and in biologically purified effluents and in polluted streams. The determination of nitrite is of considerable interest because of many reasons. Traces of nitrite and nitrate in drinking water may lead to methemoglobinemia in infants and with long term exposure is possible cancer risk. Nitrite can react with secondary amines present in the body resulting in the formation of

* e-mail: nbadiadka@yahoo.co.uk carcinogenic nitrosamines. ${ }^{2-4}$ The reduction of nitrate to nitrite is possible in the stomach of infants, where low acidity allows the growth of nitrite-reducing microorganisms. Nitrite levels, when correlated with other forms of nitrogen in waters, provide indexes of organic pollution in water. ${ }^{5}$ General procedures for the determination of nitrites are usually based up on some form of diazotization reaction. AOAC official method of analysis for nitrite and nitrate determination was based on the diazocoupling reaction between sulfanilamide and $\mathrm{N}$-(1-naphthyl) ethylenediamine hydrochloride. ${ }^{6}$ This method required careful control of acidity in each step of the process and generates carcinogenic ${ }^{7}$ compound when naphthalene nucleus is present. Some of the reported methods for the determination of nitrite are kinetic, ${ }^{8,9}$ chromatographic, ${ }^{10}$ and flow injection. ${ }^{11}$ The spectrophotometric methods for the determination of nitrite are summarized in Table 1. Some method often involve carcinogenic materials for the 
determination of nitrite, as the naphthylamines and some others have non-linear calibration graph, lack of sensitivity, selectivity and involves rigorous experimental conditions.

The present work introduces new coupling agents, ethoxyethylenemaleic ester and ethylcyanoacetate for the selective and rapid spectrophotometric determination of nitrite in water and soil samples without involving complicated steps. $p$-Nitroaniline is diazotized in acidic medium, and coupled with ethoxyethylene maleic ester or ethyl cyanoacetate to give water-soluble colored dyes in alkaline medium having absorption maximum at 439 and $465 \mathrm{~nm}$ respectively. The method has been successfully applied to the determination of nitrite in various water samples and soil samples.

\section{Experimental}

\section{Apparatus}

A Secomam Anthelie NUA 022 UV-VIS spectrophotometer with $1 \mathrm{~cm}$ quartz cell was used for the absorbance measurements and a WTW pH 330, pH meter were used.

\section{Reagents}

All chemicals used were of analytical reagent grade (Merck) or chemically pure grade and double distilled water was used for the dilution of reagents and samples. Standard nitrite $\left(1000 \mu \mathrm{g} \mathrm{mL}^{-1}\right)$ was prepared by dissolving $0.150 \mathrm{~g}$ sodium nitrite in water and diluting to $100 \mathrm{~mL}$, preserved with $2 \mathrm{~mL}$ chloroform. A $(0.05 \%)$ solution of $p$-nitroaniline, ethoxyethylenemaleic ester (5\%), ethylcyanoacetate $(5 \%)$, hydrochloric acid $\left(0.25 \mathrm{~mol} \mathrm{~L}^{-1}\right)$, sodium hydroxide $(5 \mathrm{~mol} \mathrm{~L}-1)$, EDTA $\left(0.02 \mathrm{~mol} \mathrm{~L}^{-1}\right)$ and sodium carbonate (1\%) were used.

\section{General procedure for the determination of nitrite}

An aliquot of the sample solution containing 0.2 $20 \mu \mathrm{g} \mathrm{mL} \mathrm{m}^{-1}$ of nitrite was transferred to a series of 10 $\mathrm{mL}$ calibrated flasks. To this solution $1 \mathrm{~mL}$ of $0.05 \%$ $p$-nitroaniline and $0.5 \mathrm{~mL}$ of $0.25 \mathrm{~mol} \mathrm{~L}^{-1}$ hydrochloric acid were added and the solution was shaken thoroughly for 2 minutes to allow the diazotization reaction to go to completion. Then, volumes of $1 \mathrm{~mL}$ of $2 \%$ ethoxyethylenemaleic ester or ethylcyanoacetate and $2 \mathrm{~mL}$ of $5 \mathrm{~mol} \mathrm{~L}^{-1}$ sodium hydroxide solutions were added and the contents were diluted to $10 \mathrm{~mL}$ using double distilled water and mixed well. After 5 minutes, the absorbance of the colored azo dyes was measured at 439 or $465 \mathrm{~nm}$ against the reagent blank.

Determination of nitrite in water samples ${ }^{19}$

A $5 \mathrm{~mL}$ of water sample (containing not more than 10 $\mu \mathrm{g} \mathrm{mL} \mathrm{m}^{-1}$ of nitrite) was treated with $0.5 \mathrm{~mL}$ of $1 \mathrm{~mol} \mathrm{~L}^{-1}$ $\mathrm{NaOH}$ and $0.5 \mathrm{~mL}$ of $0.2 \mathrm{~mol} \mathrm{~L}^{-1}$ EDTA. The solution was mixed and centrifuged to remove any precipitate formed. The centrifugate was transferred to a $10 \mathrm{~mL}$ standard flask and directly used for the color development by following the procedure described above. The concentration of the nitrite was established by reference

Table 1. Comparison to the spectrophotometric methods for the determination nitrite

\begin{tabular}{|c|c|c|c|c|}
\hline Reagent & Range $\left(\mu g \mathrm{~mL}^{-1}\right)$ & $\lambda_{\max }(\mathrm{nm})$ & Remarks & Ref. \\
\hline $\mathrm{SA}+\mathrm{NEDH}$ & $0.5-14$ & 540 & $\mathrm{pH}$ sensitive & 6 \\
\hline p-Aminophenyl mercaotoacetic acid & $0.01-1.6$ & 495 & $\mathrm{~S}^{2-}$ and $\mathrm{Sb}^{3+}$ interfere & 12 \\
\hline$p$-Aminoacetophenone+ NEDH & $0.1-0.8$ & 546 & Less sensitive & 13 \\
\hline$o$-Nitroaniline +1 -Aminonaphthalene & $0.08-0.68$ & 545 & Less selective & 14 \\
\hline PNA+ Phloroglucinol & $0.004-0.04$ & 420 & Less selective & 15 \\
\hline PNA+Acetylacetone & $0.5-14$ & 490 & $\mathrm{Cu}^{2+}, \mathrm{Fe}^{3+}, \mathrm{Co}^{2+}$ and $\mathrm{Hg}^{2+}$ interfere & 16 \\
\hline Phosphomolybdenum blue & $0.5-2.0$ & 814 & Less sensitive & 17 \\
\hline $\mathrm{PNA}+\mathrm{EA}$ & $0.05-6.0$ & 507 & Less sensitive & 18 \\
\hline $\mathrm{SA}+\mathrm{EAA}$ & $0.2-3.0$ & 356 & Less sensitive & 18 \\
\hline PAA+ Citrazinic acid & $0.5-12$ & 495 & $\mathrm{Fe}^{3+}, \mathrm{Cu}^{2+}$ interfere & 19 \\
\hline Leucocrystal violet & $0.004-0.04$ & 500 & $\mathrm{Tl}^{3+}, \mathrm{Ce}^{4+}$ and $\mathrm{Cu}^{2+}$ interfere & 20 \\
\hline 4,4'-Diaminostilbene-2,2'-di-sulfonic acid & $0.04-1.6$ & 520 & $\mathrm{Hg}^{2+}$ and $\mathrm{Fe}^{3+}$ interfere & 21 \\
\hline PNA + Citrazinic acid & $0.5-14.0$ & 530 & $\mathrm{Hg}^{2+}$ and $\mathrm{Cr}^{6+}$ interfere & 22 \\
\hline PNA+ Guaiacol & $0.03-0.15$ & 540 & Extractive, $\mathrm{NO}_{3}^{-}, \mathrm{Al}^{3+}$ interferes & 23 \\
\hline 4-Nitroaniline + 1-Naphthol & $0.02-0.14$ & 610 & Extractive, less sensitive & 24 \\
\hline \multicolumn{5}{|l|}{ Proposed } \\
\hline PNA+EMME & $0.5-16$ & 439 & \multicolumn{2}{|c|}{ Simple sensitive, common ions do not interfere } \\
\hline $\mathrm{PNA}+\mathrm{ECA}$ & $0.2-18$ & 459 & Idem & \\
\hline
\end{tabular}

NEDH,N-(1-naphthyl)ethylenediamine hydrochloride; PNA, $p$-nitroaniline; SA,sulfanimide; EAA, ethyl acetoacetate; PAA, $p$-aminoacetophenone;.EMME, ethoxyethylenemaleic ester, ECA, ethylcyanoacetate. 
with a calibration graph prepared using $0.2-20 \mu \mathrm{g} \mathrm{mL} \mathrm{m}^{-1}$ of nitrite in $10 \mathrm{~mL}$ standard flasks using distilled water.

\section{Determination of nitrite in soil samples ${ }^{19}$}

About $1 \mathrm{~g}$ of soil sample was weighed $(0.9931 \mathrm{~g}$ and $0.9894 \mathrm{~g}$ respectively) and placed in a $50 \mathrm{~mL}$ beaker and then extracted 4 times with $5 \mathrm{~mL}$ portions of $1 \%$ sodium carbonate. The extract was filtered and made up to $25 \mathrm{~mL}$ with distilled water. Suitable aliquot of the sample solution was directly used for the analysis of nitrite in soil samples.

\section{Results and Discussion}

The method involves the diazotization of $p$-nitroaniline, followed by the coupling of ethoxyethylenemaleic ester or ethylcyanoacetate in alkaline medium (Scheme 1). The absorption spectra of the azo dyes formed between $p$-nitroaniline-ethoxyethylenemaleic ester and $p$-nitroanilineethylcyanoacetate have absorption maxima at 439 and 465 $\mathrm{nm}$ respectively (Figure 1).

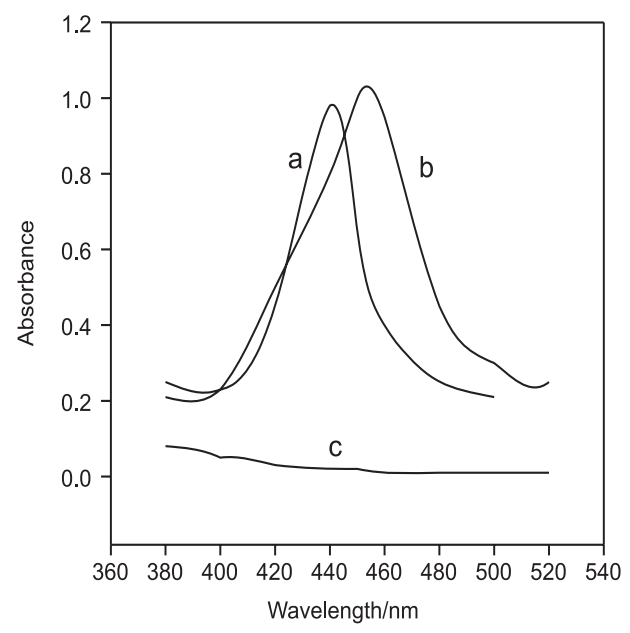

Figure 1. Absorption spectra of diazocouple of $p$-nitroaniline and ethoxyethylene maleic ester $v s$. reagent blank (a), Absorption spectra of diazocouple of $p$-nitroaniline and ethylcyanoacetate $v s$. reagent blank (b) and reagent blank $v s$. distilled water (c).
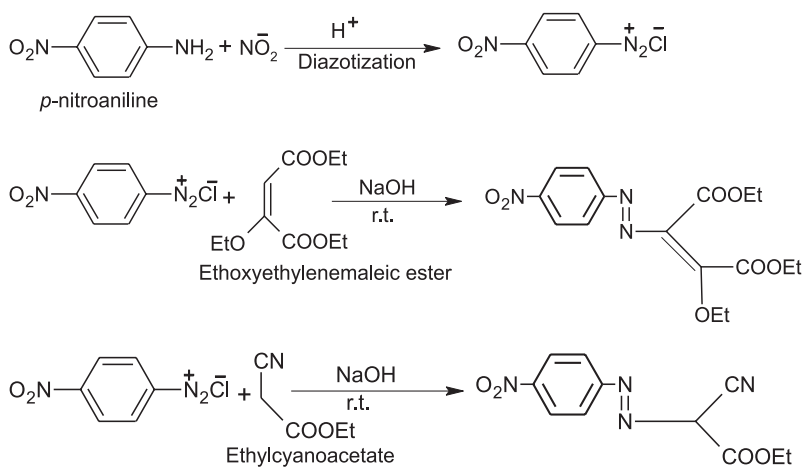

Scheme 1.
Effect of acid concentration and temperature on diazotization

Diazotization and coupling reactions were found to be temperature dependent. Diazotization was carried out at $0-5{ }^{\circ} \mathrm{C}$ and coupling reactions wass carried out at room temperature. Above $50{ }^{\circ} \mathrm{C}$ there is a decrease in intensity of the color. The effect of acidity on the diazotization reaction was studied in the range $0.1-0.5 \mathrm{~mol} \mathrm{~L}^{-1}$ hydrochloric acid, and constant absorbance was observed in this range. Above this range, a decrease in the absorbance was observed. The optimum acidity for the diazotization was fixed at $0.25 \mathrm{~mol} \mathrm{~L}^{-1}$ and minimum time for the complete diazotization was found to be 2 minutes.

\section{The effect of the p-nitroaniline concentration}

The effect of the $p$-nitroaniline concentration on the color intensity was studied using the proposed procedure and adding $1 \mathrm{~mL}$ of $1-4 \%$ solutions of $p$-nitroaniline in hydrochloric acid $\left(0.25 \mathrm{~mol} \mathrm{~L}^{-1}\right)$ to a series of nitrite solutions. The results showed that a $2 \%$-nitroaniline solution was sufficient for complete color development. Higher concentration did not enhance the absorbance further, and lower concentration did not give good results.

\section{Effect of coupling agent}

The effect of varying the concentration of coupling agent was studied using the proposed procedure and adding 0.2$2.0 \mathrm{~mL}$ of $2 \%$ ethoxyethylenemaleic ester or $0.2-2.0 \mathrm{~mL}$ of $2 \%$ ethylcyanoacetate to a series of nitrite solutions. It was found that maximum and stable color was formed with 1 $\mathrm{mL}$ of each ethoxyethylenemaleic ester (2\%) or ethylcyanoacetate $(2 \%)$ solution in a final volume of $10 \mathrm{~mL}$.

\section{Effect of sodium hydroxide concentration}

The effect of sodium hydroxide concentration on the absorbance was studied; volumes from $0.1-1.0 \mathrm{~mL}$ of 5 mol L-1 sodium hydroxide solutions were examined. The investigations showed that $0.4-0.5 \mathrm{~mL}$ of $\mathrm{NaOH}$ gave maximum absorbance and $0.5 \mathrm{~mL}$ of $5 \mathrm{~mol} \mathrm{~L}^{-1} \mathrm{NaOH}$ solutions was chosen for the procedure. Other alkaline solutions were tried, but best results were obtained by using sodium hydroxide.

\section{Analytical data}

The agreement of Beer's law was studied by measuring the absorbance values of solutions varying nitrite 
concentration. A straight line graph was obtained by plotting absorbance against concentration of nitrite. This method obeys Beer's law in the concentration range of $0.5-16 \mu \mathrm{g} \mathrm{mL}-1$ for nitrite with $p$-nitroaniline-ethoxyethylenemaleic ester and $0.2-18 \mu \mathrm{g} \mathrm{mL}^{-1}$ for nitrite with $p$-nitroaniline-ethylcyanoacetate couples. The molar absorptivity, Sandell's sensitivity of colored system with $p$-nitroaniline- ethoxyethylenemaleic ester and $p$-nitroaniline-ethylcyanoacetate couples were found to be $5.04 \times 10^{4} \mathrm{~L} \mathrm{~mol}^{-1} \mathrm{~cm}^{-1}, 0.98 \times 10^{-2} \mu \mathrm{g} \mathrm{cm}^{-2}$ and $1.21 \times 10^{4}$ $\mathrm{L} \mathrm{mol}^{-1} \mathrm{~cm}^{-1}, 0.98 \times 10^{-2} \mu \mathrm{g} \mathrm{cm}^{-2}$ respectively. The detection limit $\left(\mathrm{D}_{\mathrm{L}}=3.3 \sigma / \mathrm{S}\right)$ and quantitation limit $\left(\mathrm{Q}_{\mathrm{L}}=10 \sigma / \mathrm{S}\right)$ [where $\sigma$ is the standard deviation of the reagent blank $(n=5)$ and $S$ is the slope of the calibration curve ] for the nitrite determination with $p$-nitroaniline-ethoxyethylenemaleic ester diazocouple and $p$-nitroanilineethylcyanoacetate diazocouple were found to be $0.07 \mu \mathrm{g}$ $\mathrm{mL}^{-1}, 0.21 \mu \mathrm{g} \mathrm{mL}^{-1}$ and $0.05 \mu \mathrm{g} \mathrm{mL}^{-1}, 0.15 \mu \mathrm{g} \mathrm{mL}^{-1}$.

The stability of the reagents and also the reliability of the proposed method were tested by determining the concentration of 10 samples containing $2 \mu \mathrm{g} \mathrm{mL}^{-1}$ nitrite per $10 \mathrm{~mL}$ over a period of $6 \mathrm{~h}$, the mean absorbance was found to be 0.6 and relative standard deviation $1.5 \%$ respectively. The results showed no systematic error in the method and thus indicate its reliability.

\section{Effect of interfering species}

The effect of other ions on the determination of nitrite using the proposed method was studied for solutions containing $5 \mu \mathrm{g} \mathrm{mL}^{-1}$ nitrite. Metal ions forming hydroxides in alkaline medium such as $\mathrm{Co}(\mathrm{II}), \mathrm{Cu}(\mathrm{II})$, $\mathrm{Hg}$ (II), and $\mathrm{Fe}$ (III) were found to interfere, but a large number of these ions were masked with EDTA. Iron(III) was masked using sodium fluoride. The tolerance limit of the foreign ions is shown in Table 2 as the amounts that caused not more than $\pm 2 \%$ changes in the values of absorbance during the determinations.

Table 2. Effect of diverse ions on the determination of nitrite $\left(5 \mu \mathrm{g} \mathrm{mL}^{-1}\right)$

\begin{tabular}{lccc}
\hline ion & $\begin{array}{c}\text { Tolerance } \\
\text { limit }\left(\mu \mathrm{gL} \mathrm{mL}^{-1}\right)\end{array}$ & ion & $\begin{array}{c}\text { Tolerance } \\
\text { limit }\left(\mu \mathrm{gL} \mathrm{m}^{-1}\right)\end{array}$ \\
\hline $\mathrm{Ba}(\mathrm{II})$ & 500 & Fluoride & 2000 \\
$\mathrm{Cd}(\mathrm{II})$ & 500 & Iodide & 2000 \\
$\mathrm{Ca}(\mathrm{II})$ & 200 & Tartrate & 1000 \\
$\mathrm{Co}(\mathrm{II})^{*}$ & 100 & Citrate & 1000 \\
$\mathrm{Cu}(\mathrm{II})^{*}$ & 100 & Acetate & 1000 \\
$\mathrm{~Pb}(\mathrm{II})$ & 200 & Oxalate & 1000 \\
$\mathrm{Mn}(\mathrm{II})$ & 200 & Sulfate & 1200 \\
$\mathrm{Mg}(\mathrm{II})$ & 200 & Chloride & 1000 \\
$\mathrm{Hg}(\mathrm{II})^{*}$ & 50 & Nitrate & 1000 \\
$\mathrm{Al}(\mathrm{III})$ & 500 & Phosphate & 1000 \\
$\mathrm{Fe}(\mathrm{III})^{*}$ & 75 & & \\
$\mathrm{Cr}(\mathrm{VI})$ & 100 & & \\
\hline
\end{tabular}

* Masked with masking agents.

\section{Applications}

The proposed methods were applied to the determination of nitrite in water and soil samples. The water samples were collected from different sources, and were filtered before analysis. As the concentration of common pollutants in the natural water is generally far below the tolerance levels shown in Table 2, the method was applied directly to the determination of nitrite in natural water samples. The results obtained are compared with the standard sulfanilamideNEDA $^{6}$ method (Tables 3 and 4). Statistical analysis of the results by $t$ and F-tests showed no significant difference in accuracy and precision of the proposed and reference method. ${ }^{6}$ The reliability of the method to analyze real samples was checked by recovery experiments, which gave quantitative results with convenient reproducibility.

Table 3. Determination of nitrite in different water and soil samples using diazocouple of $p$-nitroaniline with ethoxyethylenemaleic ester

\begin{tabular}{|c|c|c|c|c|c|c|c|}
\hline \multirow[t]{2}{*}{ Samples } & \multirow{2}{*}{ 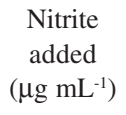 } & \multicolumn{2}{|c|}{ Proposed method } & \multicolumn{2}{|c|}{ Reference method } & \multirow[t]{2}{*}{$t$-test $\mathrm{t}^{\mathrm{b}}$} & \multirow[t]{2}{*}{ F-test ${ }^{\mathrm{c}}$} \\
\hline & & $\begin{array}{c}\mathrm{NO}_{2}^{-} \text {found } \\
\pm \mathrm{SD}^{\mathrm{a}}\left(\mu \mathrm{g} \mathrm{mL}^{-1}\right)\end{array}$ & $\begin{array}{c}\text { Recovery } \\
\%\end{array}$ & $\begin{array}{c}\mathrm{NO}_{2}^{-} \text {found } \\
\pm \mathrm{SD}^{\mathrm{a}}\left(\mu \mathrm{g} \mathrm{mL}^{-1}\right)\end{array}$ & $\begin{array}{c}\text { Recovery } \\
\%\end{array}$ & & \\
\hline \multirow[t]{2}{*}{ Tap water ${ }^{\mathrm{d}}$} & 5.0 & $4.97 \pm 0.02$ & 99.4 & $4.94 \pm 0.03$ & 98.8 & 1.86 & 2.25 \\
\hline & 10.0 & $9.98 \pm 0.04$ & 99.8 & $9.95 \pm 0.03$ & 99.5 & 1.34 & 1.78 \\
\hline \multirow[t]{3}{*}{ Ground water } & - & $0.93 \pm 0.04$ & - & $0.95 \pm 0.03$ & - & 0.89 & 1.78 \\
\hline & 5.0 & $5.94 \pm 0.03$ & 100.2 & $5.92 \pm 0.05$ & 99.4 & 0.77 & 2.78 \\
\hline & 10.0 & $10.89 \pm 0.02$ & 99.6 & $10.87 \pm 0.04$ & 99.2 & 1.01 & 4.00 \\
\hline \multirow{3}{*}{ River water } & - & $1.05 \pm 0.05$ & - & $1.01 \pm 0.04$ & - & 1.05 & 1.56 \\
\hline & 5.0 & $6.03 \pm 0.05$ & 99.6 & $5.97 \pm 0.07$ & 99.0 & 1.56 & 1.96 \\
\hline & 10.0 & $11.0 \pm 0.02$ & 99.5 & $10.99 \pm 0.03$ & 99.8 & 0.62 & 2.25 \\
\hline \multirow[t]{3}{*}{ Soil } & - & $1.02 \pm 0.02$ & - & $1.03 \pm 0.03$ & - & 0.62 & 2.25 \\
\hline & 6.0 & $6.97 \pm 0.04$ & 99.2 & $6.93 \pm 0.06$ & 98.3 & 1.24 & 2.25 \\
\hline & 12.0 & $12.99 \pm 0.02$ & 99.7 & $12.97 \pm 0.03$ & 99.5 & 1.24 & 2.25 \\
\hline
\end{tabular}

${ }^{\mathrm{a}}$ Mean \pm standard deviation $(\mathrm{n}=5){ }^{\mathrm{b}}{ }^{\mathrm{t}}$ tabulated $t$-value for 8 degrees of freedom at $\mathrm{P}(0.95)$ is $2.306 ;{ }^{\mathrm{c}}$ tabulated F-value for $(4,4)$ degrees of freedom at $\mathrm{P}(0.95)$ is $6.39 ;{ }^{\mathrm{d}}$ tap water gave no test for nitrite. 
Table 4. Determination of nitrite in different water and soil samples using diazocouple of $p$-nitroaniline with ethylcyanoacetate

\begin{tabular}{|c|c|c|c|c|c|c|c|}
\hline \multirow[t]{2}{*}{ Samples } & \multirow{2}{*}{$\begin{array}{c}\text { Nitrite } \\
\text { added } \\
\left(\mu \mathrm{g} \mathrm{mL} \mathrm{m}^{-1}\right)\end{array}$} & \multicolumn{2}{|c|}{ Proposed method } & \multicolumn{2}{|c|}{ Reference method } & \multirow[t]{2}{*}{$t$-test ${ }^{\mathrm{b}}$} & \multirow[t]{2}{*}{ F-test ${ }^{\mathrm{c}}$} \\
\hline & & $\begin{array}{c}\mathrm{NO}_{2}^{-} \text {found } \\
\pm \mathrm{SD}^{\mathrm{a}}\left(\mu \mathrm{g} \mathrm{mL}^{-1}\right)\end{array}$ & $\begin{array}{c}\text { Recovery } \\
\%\end{array}$ & $\begin{array}{c}\mathrm{NO}_{2}^{-} \text {found } \\
\pm \mathrm{SD}^{\mathrm{a}}\left(\mu \mathrm{g} \mathrm{mL} \mathrm{L}^{-1}\right)\end{array}$ & $\begin{array}{c}\text { Recovery } \\
\%\end{array}$ & & \\
\hline \multirow[t]{2}{*}{ Tap $^{\mathrm{d}}$ water } & 7.0 & $6.98 \pm 0.03$ & 99.7 & $6.95 \pm 0.04$ & 99.2 & 1.34 & 1.78 \\
\hline & 14.0 & $13.95 \pm 0.02$ & 99.6 & $13.92 \pm 0.03$ & 99.4 & 1.86 & 2.25 \\
\hline \multirow[t]{3}{*}{ Ground water } & - & $0.92 \pm 0.02$ & - & $0.95 \pm 0.03$ & - & 1.86 & 2.25 \\
\hline & 7.0 & $7.93 \pm 0.05$ & 100.1 & $7.92 \pm 0.03$ & 99.6 & 0.38 & 2.78 \\
\hline & 14.0 & $14.90 \pm 0.07$ & 99.8 & $14.92 \pm 0.05$ & 99.7 & 0.52 & 1.96 \\
\hline \multirow[t]{3}{*}{ River water } & - & $1.04 \pm 0.02$ & - & $1.01 \pm 0.04$ & - & 1.49 & 4.00 \\
\hline & 7.0 & $7.97 \pm 0.02$ & 99.0 & $7.95 \pm 0.03$ & 99.1 & 1.24 & 2.25 \\
\hline & 14.0 & $15.01 \pm 0.01$ & 99.8 & $14.98 \pm 0.02$ & 99.7 & 2.99 & 4.00 \\
\hline \multirow[t]{3}{*}{ Soil } & - & $1.05 \pm 0.02$ & - & $1.03 \pm 0.03$ & - & 1.24 & 2.25 \\
\hline & 7.0 & $8.01 \pm 0.03$ & 99.4 & $7.99 \pm 0.04$ & 99.4 & 0.89 & 1.78 \\
\hline & 14.0 & $15.06 \pm 0.04$ & 100.1 & $15.00 \pm 0.06$ & 99.8 & 2.94 & 2.25 \\
\hline
\end{tabular}

${ }^{a}$ Mean \pm standard deviation $(\mathrm{n}=5)$; ${ }^{\mathrm{b}}$ tabulated $t$-value for 8 degrees of freedom at $\mathrm{P}(0.95)$ is $2.306 ;{ }^{\mathrm{c}}$ tabulated F-value for $(4,4)$ degrees of freedom at $\mathrm{P}$ $(0.95)$ is $6.39 ;{ }^{\mathrm{d}}$ tap water gave no test for nitrite.

\section{Conclusions}

The proposed method for the determination of nitrite is simple and sensitive has a wide analytical range without the need for extraction or heating. The reagent proposed has the advantage of high sensitivity and low absorbance of reagent blank. The developed method does not involve any stringent reaction conditions and offers the advantages of high color stability (more than 6 hours). The proposed method has been successfully applied to the determination of trace amounts of nitrite in water and soil samples.

\section{Acknowledgments}

Authors also thank the Microtron facility Center, Mangalore University for technical help.

\section{References}

1. BIBRA working Group, Toxicity Profile, BIBRA,; Toxicol. Int. 1990, 12.

2. Hurst, J. K.; Lumar, S. V.; Chem. Res. Toxicol. 1997, 10, 804.

3. Reszka, K. J.; Matuszak, Z.; Chignell.; C. F.; Chem. Res. Toxicol. 1997, 10, 1325.

4. Wang, C. J.; Huang, H. P.; Tseng, T. H.; Lin, Y. L.; Shiow, S. J.; Arch. Toxicol. 1995, 70, 12.

5. Gabby, J.; Almong, Y.; Davidson, M.; Donagi, A. E.; Analyst 1997, 102, 371

6. AOAC Method; Official Methods of Analysis, $16^{\text {th }}$ ed., AOAC, 1995, 8-9.

7. Allen, A. A.; Chemical Analysis of Ecological Material, Blackwell: Oxford, 1974, p. 203.
8. Ghasemi, J.; Jabbari, A.; Amini, A.; Oskoei, A. G.; Abdolahi, B.; Anal. Lett. 2004, 37, 2205.

9. Tomiyasu, T.; Konagayoshi,Y.; Anazawa, K.; Sakamoto, H.; Anal. Sci. 2001, 17, 1437.

10. Mou, S. F.; Wang, T. H.; Sun, Q. J.; J. Chromatogr. 1993, 640, 161.

11. Andrade, R.; Viana, C.O.; Guadagnin, S. G.; Reyes, F. G. R.; Rath, S.; Food Chem. 2003, 80, 597.

12. Rathore, D. P. S.; Tarafder, P. K.; J. Indian. Chem. Soc. 1989, 26, 185.

13. Kaur, P.; Gupta, V. K.; J. Indian. Chem. Soc. 1987, 64, 428.

14. Kaveeshwar, R.; Gupta, V. K.; Analyst, 1991, 116, 667.

15. Kesari, R.; Gupta, V. K.; J. Indian. Chem. Soc. 1998, 75, 416.

16. Revanasiddappa, H. D.; Kumar, K.; Bilwa, M.; Mikrochim. Acta 2001, 137, 249.

17. Nidal, A. Z.; Maher, A. A.; Abdullah, F. E.; Talanta 1999, 50, 819.

18. Sreekumar, N. V.; Narayana, B.; Hegde, P.; Munjunatha, B. R.; Sarojini, B. K.; Microchem. J. 2003, 74, 27.

19. Revanasiddappa, H. D.; Kiran Kumar, T. N.; Fresenius Environ. Bull. 2001, 10, 781.

20. Sukumar, C.; Sunitha, M. B.; Gupta, V. K;. J. Indian Chem. Soc. 2004, 81, 522.

21. Reddy, M. C. S.; J. Sci. Indust. Res. 2004, 63, 172.

22. Revanasiddappa, H. D.; Kiran Kumar, T. N.; Chem. Anal. (Warsaw) 2003, 48, 759 .

23. Sunitha, S.; Gupta, V.K.; Intern. J. Environ. Anal. Chem. 1984, $19,11$.

24. Baveja, A. K.; Gupta, V.K.; Analyst 1981, 106, 955.

Received: July 7, 2005 Published on the web: April 12, 2006 